\title{
Consumption, apparent digestibility and nutrient balance of diets with bovine milk whey for goats
}

\section{Consumo, digestibilidade aparente e balanço de nutrientes de dietas com soro de leite bovino para caprinos}

\author{
Alexandre Ribeiro Araújo ${ }^{1}$; James Pierre Muir ${ }^{2}$; Angela Maria de Vasconcelos ${ }^{3}$; \\ Roberto Cláudio Fernandes Franco Pompeu ${ }^{4}$; Luciana Freitas Guedes ${ }^{4}$; Clésio dos \\ Santos Costa 5 ; Maria Socorro de Sousa Carneiro5; Warley Éfrem Campos ${ }^{6}$; Marcos \\ Cláudio Pinheiro Rogério ${ }^{*}$
}

\author{
Highlights: \\ Bovine whey is a feed alternative for goats. \\ Whey can be included up to $4.5 \%$ of goat diet. \\ Whey does not change goat production parameters.
}

\begin{abstract}
Increasing milk production in countries such as Brazil, India and Pakistan implies the generation of dairy by-products such as nutrient-rich bovine whey which, if used in feeding small ruminants would reduce environmental waste and add value to this by-product. Twenty entire male kids weighing an average $17 \mathrm{~kg}$ and 5 months age were used. The diet control was composed by Aruana hay, milled whole maize, pelleted soybean and limestone. Bovine cheese whey at 1.5; 3.0 and 4.5\% (DM basis) was added to experimental diets. Variables measured included intake, nutrient apparent digestibility, energy balance, and nitrogen balance. Regression equations and Pearson correlations $(P \leq 0.05)$ were determined. The $3 \%$ diet resulted in greater ether extract $(\mathrm{EE})\left(\mathrm{g} / \mathrm{kg}^{0.75}\right)$ and digestible $\mathrm{EE}(P \leq 0.05)$ concentrations compared to $0 \%$ whey. The consumption of cellulose $\left(\mathrm{g} / \mathrm{kg}^{0.75}\right)$ was greater $(P \leq 0.05)$ for kids on the $3.0 \%$ diet compared to 0 or $1.5 \%$. Nutrient apparent digestibility was not affected $(P>$ $0.05)$ by the inclusion of whey. Kids on the $4.5 \%$ diet excreted more $(P \leq 0.05)$ fecal $\mathrm{N}$ than those fed no whey; these also retained less $\mathrm{N}(P \leq 0.05)$ compared to animals fed $3.0 \%$ or less whey in their diet. All diets resulted in positive energy and nitrogen balances. Bovine whey can be included in male kid diets up to $4.5 \%$ of diet without negatively affecting consumption or apparent digestibility of those diets.
\end{abstract}

Key words: Dairy by-products. Feed. Kids. Nutrition.

1 Prof. Dr., Universidade Federal do Piauí, UFPI, Floriano, PI, Brasil. E-mail: alexandre.xandyzoo@gmail.com

2 Researcher, Texas A\&M AgriLife Research, Stephenville, TX, USA. E-mail: jim.Muir@ag.tamu.edu

3 Prof $^{\mathrm{a}} \mathrm{Dr}^{\mathrm{a}}$, Universidade Vale do Acaraú, UVA, Sobral, CE, Brasil. E-mail: angv06@hotmail.com

4 Pesquisadores, Empresa Brasileira de Pesquisa Agropecuária, EMBRAPA Caprinos e Ovinos, Sobral, CE, Brasil. E-mail: roberto.pompeu@embrapa.br; lucianafguedes@gmail.com; marcosclaudio@gmail.com

5 Discentes de Doutorado, Programa de Doutorado Integrado em Zootecnia, Universidade Federal do Ceará, UFC, Fortaleza, CE, Brasil. E-mail: clesiosantzoo@gmail.com; msocorro@ufc.br

6 Médico Veterinário, Fiscal Federal Agropecuário, Ministério da Agricultura, Pecuária e Abastecimento, MAPA, Brasília, DF, Brasil. E-mail: warley.campos@agricultura.gov.br

* Author for correspondence 
O aumento da produção de leite em países como Brasil, Índia e Paquistão implica na geração de coprodutos lácteos, como o soro bovino rico em nutrientes, e cuja utilização na alimentação de pequenos ruminantes reduziria o desperdício e menores impactos na poluição ambiental, além de agregar valor a esse coproduto. Foram utilizados 20 cabritos sem padrão racial definido, com peso vivo médio de $17 \mathrm{~kg}$ e cinco meses de idade. A dieta controle foi composta por feno de capim Aruana, milho moído, farelo de soja e calcário. Para as dietas teste, foram adicionados 1,5; 3,0 e 4,5\% (base de matéria seca) de soro de leite bovino. As variáveis estudadas foram o consumo e digestibilidade aparente dos nutrientes, o balanço energético e o balanço de nitrogênio. Equações de regressão e correlações de Pearson $(\mathrm{P} \leq$ $0,05)$ foram determinadas. A dieta a $3 \%$ resultou em maior concentração de extrato etéreo (EE) (g/ $\left.\mathrm{kg}^{0,75}\right)$ e EE digestível $(\mathrm{P} \leq 0,05)$ em comparação com $0 \%$ de soro de leite. O consumo de celulose $\left(\mathrm{g} / \mathrm{kg}^{0,75}\right)$ foi maior $(\mathrm{P} \leq 0,05)$ para caprinos machos inteiros na dieta $3,0 \%$ comparado a 0 ou $1,5 \%$. A digestibilidade aparente dos nutrientes não foi afetada $(P>0,05)$ pela inclusão de soro de leite. Os animais que receberam a dieta com $4,5 \%$ excretaram mais $(\mathrm{P} \leq 0,05) \mathrm{N}$ fecal do que aquelas que não receberam soro de leite; estes cabritos machos inteiros também retiveram menos $\mathrm{N}(\mathrm{P} \leq 0,05) \mathrm{em}$ comparação com animais alimentados com $3,0 \%$ ou menos de soro de leite em sua dieta. Todas as dietas resultaram em balanços positivos de energia e nitrogênio. O soro bovino pode ser incluído em dietas para caprinos em até $4,5 \%$ da dieta sem afetar negativamente o consumo ou a digestibilidade aparente. Palavras-chave: Alimento. Crias. Nutrição. Coprodutos lácteos.

\section{Introduction}

The dairy industry has been growing in recent years, presenting a wide variety of products. Milk, yoghurt, cheese, butter and ice-cream are common products of this industry (Kanza, Sameen, Khan, Shariati, \& Hristova, 2017). When cheese and casein production from milk occurs, whey is the liquid portion of this production (Yadav et al., 2015). Worldwide whey production is estimated to be approximately 180 to $190 \times 10^{6} \mathrm{Mg}$ year, and approximately $50 \%$ of this amount is processed (Mollea, Molea, \& Bosco, 2013). El-Tanboly, ElHofi and Korshid (2017) reported that about half of this processed amount is used in liquid form, 30\% as powered cheese-whey, $15 \%$ as lactose and its coproducts and the rest as protein concentrates.

Nutritionists recommend including dairy products in human diets to achieve healthier nutrition. Whey proteins are recommended in sport nutrition due its muscle development capability during exercise training (Kanza et al., 2017). It also enhances strength of muscles as well as prevents osteoporosis and cardiovascular diseases (Bjorkman, Finne-Soveri, \& Tilvis, 2012).
However, about $50 \%$ of unprocessed whey is wasted and represents an environmental and economic challenge. According to Yadav et al. (2015), when discharged into water bodies, it reduces dissolved oxygen and causes high biochemical oxygen demand (BOD). In soils it can affect the physicochemical characteristics of soil resulting in decreased crop yields. Unused whey represents an economic loss which could, instead, provide economical animal feed.

The use of whey in animal feed can take the form of milk replacer to calves (Huuskonen, 2017), supplements to lactating cattle diet (El-Shewy, 2016), improved broiler growth (Kanza et al., 2017), and feed supplement to growing pigs (Martins, Pimenta, Costa, \& Souza, 2008) as well as growing lambs (Rogério et al., 2019).

Considering the relevance of goat production worldwide, taking advantage of whey where the dairy industry is growing, using whey for kid diets may be an option. Cheese whey represents about 90 $95 \%$ of the milk volume and retains about $55 \%$ of milk nutrients; this byproduct is abundant in lactose $(4.5-5.0 \% \mathrm{w} / \mathrm{v})$, soluble proteins $(0.6-0.8 \%$ 
$\mathrm{w} / \mathrm{v})$, lipids $(0.4-0.5 \% \mathrm{w} / \mathrm{v})$ and mineral salts $(8.0$

$-10.0 \% \mathrm{w} / \mathrm{v}$ of dried extract) (El-Tanboly et al., 2017). It could therefore replace traditional dietary concentrates at lower costs (Rogério et al., 2019).

The evaluation of alternative animal feeds seeks to determine their maximum inclusion and acceptability to those animals. Determining voluntary intake allows for quality evaluation and consumption rates that meet nutritional needs of those animals without negatively affecting production (Van Soest, 1994). The objective of this trial was to determine the consumption, digestibility as well as the $\mathrm{N}$ and energy balance of kids fed diets with various contents of bovine whey.

\section{Material and Methods}

The experiment took place at the Small Ruminant Nutrition Research Unit of the Vale do Acarau research farm of the Vale do Acarau State University
(Sobral, Ceara, Brazil). The Sobral, Ceara, Brazil region has a megathermic dry (BShw') climate type (classification Köppen). During the trials, according to data furnished by Fundação Cearense de Metereologia e Recursos Hídricos [FUNCEME] (2019), temperatures averaged $29.2^{\circ} \mathrm{C}$ and relative humidity was $52.9 \%$.

The rations were formulated to be isoproteic and isoenergetic for growing goats with an average 19 $\mathrm{kg} \mathrm{LW}$ and $25 \mathrm{~g}$ day $^{-1}$ gain according to National Research Council [NRC] (2007). The feed base was comprised of chopped Aruana hay (Megathyrsus maximus cv. Aruana), pelleted soybean (Glycine max) cake, milled whole maize (Zea maize) and limestone $(0 \%$ or not inclusion of whey). Experimental diets contained bovine whey resulting from fresh cheese production at $1.5,3.0$ and $4.5 \%$ of the ration on a DM basis. The chemical composition of the feeds can be seen in Table 1 while the rations are described in Table 2.

Table 1

Laboratory analyses of feed ingredients fed to growing kids

\begin{tabular}{lccccc}
\hline Nutrients (\% dry matter basis) & Aruana hay & Bovine whey & Maize & Soybean cake & Calcium \\
\hline Dry matter* & 93.4 & 7.1 & 95.1 & 95.0 & 100.0 \\
Organic matter & 91.3 & 98.8 & 98.6 & 93.8 & - \\
Crude protein (CP) & 6.45 & 13.0 & 8.91 & 50.9 & - \\
Digestible CP & 5.49 & 13.0 & 8.77 & 50.4 & - \\
Acid detergent insoluble CP & 1.52 & - & 0.85 & 2.49 & - \\
Neutral detergent insoluble CP & 0.87 & - & 0.34 & 1.40 & - \\
Neutral detergent insoluble N:total N & 23.5 & - & 9.53 & 4.88 & - \\
Neutral detergent insoluble N:total N & 13.4 & - & 3.84 & 2.75 & - \\
Ether extract & 0.76 & 8.46 & 3.48 & 4.30 & - \\
Digestible fatty acids & - & 7.46 & 2.48 & 3.30 & - \\
Neutral detergent fiber (NDF) & 69.4 & - & 19.9 & 20.2 & - \\
Digestible NDF & 51.1 & - & 6.19 & 1.84 & - \\
NDF corrected for CP and ash & 63.2 & - & 11.7 & 5.96 & - \\
Acid detergent fiber & 35.9 & - & 6.09 & 11.3 & - \\
Hemicellulose & 45.4 & - & 4.08 & 12.1 & - \\
Cellulose & 36.1 & - & 9.41 & 6.13 & - \\
& & & & & continue
\end{tabular}


continuation

\begin{tabular}{|c|c|c|c|c|c|}
\hline Lignin & 8.03 & - & 3.55 & 8.35 & - \\
\hline Ash & 8.68 & 1.22 & 1.38 & 6.17 & - \\
\hline Calcium & 0.72 & 0.43 & 0.50 & 0.57 & 38.0 \\
\hline Phosphorus & 0.33 & 0.03 & 0.32 & 0.85 & - \\
\hline Total carbohydrates & 84.1 & 77.3 & 86.2 & 38.6 & - \\
\hline Soluble carbohydrates (SCHO) & 12.9 & 77.3 & 74.5 & 32.6 & - \\
\hline Digestible SCHO & 4.17 & 75.7 & 71.6 & 25.9 & - \\
\hline Crude energy (Mcal/kg) & 4.11 & 4.04 & 4.27 & 4.63 & - \\
\hline Total digestible nutrients & 53.7 & 98.6 & 85.2 & 78.6 & - \\
\hline
\end{tabular}

The whey was mixed with maize, soybean cake, and calcium, all of which was then defined as the concentrate portion of the ration. Concentrate portions at 8:00 and 16:00 hours such that $20 \%$ feed refusals resulted per day. All animals had water and and forage was provided simultaneously in equal salt available ad libitum.

Table 2

\section{Nutritional composition (\% dry matter basis) of four diets offered to growing kids}

\begin{tabular}{|c|c|c|c|c|}
\hline & \multicolumn{4}{|c|}{ Percent of bovine whey in diet } \\
\hline & $0 \%$ & $1.5 \%$ & $3.0 \%$ & $4.5 \%$ \\
\hline Dry matter & 95.0 & 93.1 & 91.3 & 89.7 \\
\hline Organic matter & 96.5 & 96.5 & 96.6 & 96.7 \\
\hline Crude protein $(\mathrm{CP})$ & 10.5 & 10.8 & 10.8 & 10.5 \\
\hline True digestible $\mathrm{CP}$ & 10.1 & 10.5 & 10.5 & 10.1 \\
\hline Neutral detergent insoluble CP & 1.11 & 1.07 & 1.04 & 1.01 \\
\hline Acid detergent insoluble CP & 0.53 & 0.51 & 0.49 & 0.48 \\
\hline Neutral detergent insoluble N:TN* & 12.9 & 12.2 & 11.7 & 11.7 \\
\hline Acid detergent insoluble N:TN* & 6.26 & 5.82 & 5.57 & 5.58 \\
\hline Ether extract & 2.82 & 3.01 & 3.16 & 3.22 \\
\hline True digestible fatty acids & 1.88 & 2.07 & 2.21 & 2.28 \\
\hline Neutral detergent fiber (NDF) & 31.4 & 28.7 & 27.1 & 27.3 \\
\hline Digestible NDF & 17.6 & 15.8 & 14.8 & 15.1 \\
\hline NDF corrected for ash and $\mathrm{N}$ & 26.8 & 24.3 & 23.0 & 23.3 \\
\hline Acid detergent fiber & 14.1 & 12.9 & 12.2 & 12.2 \\
\hline Hemicellulose & 15.2 & 13.6 & 12.8 & 12.9 \\
\hline Cellulose & 16.1 & 14.9 & 14.3 & 14.3 \\
\hline Lignin & 4.97 & 4.74 & 4.58 & 4.49 \\
\hline Ash & 3.52 & 3.27 & 3.12 & 3.11 \\
\hline Calcium & 0.65 & 0.64 & 0.63 & 0.63 \\
\hline Phosphorus & 0.35 & 0.35 & 0.34 & 0.33 \\
\hline
\end{tabular}


continuation

\begin{tabular}{lllll} 
Total carbohydrates & 83.2 & 82.6 & 82.6 & 83.0 \\
Soluble carbohydrates & 56.4 & 58.3 & 59.6 & 59.7 \\
Digestible soluble carbohydrates & 51.8 & 54.0 & 55.4 & 55.5 \\
Crude energy (Mcal kg-1) & 4.25 & 4.24 & 4.24 & 4.23 \\
Total digestible nutrients & 76.8 & 77.9 & 78.7 & 78.9 \\
\hline
\end{tabular}

*N: nitrogen; $\mathrm{TN}$ : total nitrogen.

Twenty entire male kids of undetermined races of approximately $5.5 \mathrm{mo}$ of age and an initial average weight of $17 \pm 3.9 \mathrm{~kg}$ were used. These were treated for endoparasites (Ivermectin for nematodes and sulfa drugs for coccidia) and housed in individual metabolism cages with concrete floors, shade and equipped with watering systems, feeders, salt licks, as well as fecal and urine collectors.

The experiment lasted 33 days, 26 for adaptation and 7 for data collection. The goats were weighed at the beginning of the adaptation and data collection periods. During the collection period, samples of the offered feed, feed refusals, feces, and urine were collected daily at the same time, weighed, and subsamples prepared for laboratory analysis.

For determination of feed, feed refusals and fecal composition, dry matter (DM), ash, ether extract (EE) and crude protein (CP), methodology proposed by Silva and Queiroz (2002) was followed. Whey DM was determined by drying at $105^{\circ} \mathrm{C}$. To quantify neutral detergent fiber (NDF), acid detergent fiber (ADF), cellulose, hemicellulose and lignin, methods described by Van Soest, Robertson and Lewis (1991) were followed.

Total digestible nutrients (TDN) of experimental rations were determined according to equations proposed by Cappelle, Valadares, Coelho da Silva and Cecon, (2001), where $\mathrm{TDN}=91.6086-$ $0.69233 * \mathrm{CP}+0.47932 * \mathrm{NDF}\left(\mathrm{R}^{2}=0.71 ; P \leq 0.05\right)$ for aruana hay, $\mathrm{TDN}=91.0246-0.571588 * \mathrm{NDF}$ $\left(\mathrm{R}^{2}=0.61 ; P \leq 0.01\right)$ for maize, soybean cake and whey, and TDN $=3.71095-0.129014+1.02278 *$ $\mathrm{NDF} *$ digestible organic matter $\left(\mathrm{DOM} ; \mathrm{R}^{2}=099\right.$;
$P \leq 0.01)$ of the experimental rations. For the TDN of the experimental rations and concentration of total carbohydrates (TCHO), equations proposed by Sniffen O' Connor, Van Soest and Fox, Russel (1992) were utilized.

The experimental design was completely randomized, with four treatments (whey percentage in ration) and five replications. Animal body weights (LW) taken during the week of data collection were used as covariables within the statistical model to account for heterogeneous LW among treatments. For statistical analysis the software R (R Core Team [R], 2019) was used. Differences with probability $\leq 5 \%$ were considered significant for all comparisons. Regression analyses were used to estimate feed consumption and digestibility coefficients for the different whey contents in the rations Correlation analyses were also evaluated.

\section{Results}

There were no differences in consumption $(\mathrm{g} \mathrm{kg}$ $\mathrm{LW}^{0.75}$ ) or digestibility fractions of DM, OM, CP, NDF, ADF, hemicellulose, digestible cellulose, TCHO among the rations (Table 3). Greater consumption of EE $\left(\mathrm{g} \mathrm{kg} \mathrm{LW}^{0.75}\right)$ and digestible EE $\left(\mathrm{g} \mathrm{kg} \mathrm{LW}^{0.75}\right)$ was observed in animals fed $3.0 \%$ whey compared to those receiving $0.0 \%$. Cellulose consumption by kids fed $3.0 \%$ whey was greater compared to those fed only $1.5 \%$. No equations explained the relationship between feed intake and feed whey content. Results indicated that inclusion of whey up to $4.5 \%$ of the ration, on a DM basis, did not interfere with voluntary intake. 
Table 3

Daily nutrient intake $\left(\mathrm{g} \mathrm{kg}^{0.75}\right)$ of goats fed various percentages of bovine milk whey in their diets

\begin{tabular}{lcccccc}
\hline & \multicolumn{4}{c}{ Percent whey in diet } & \multirow{2}{*}{ RE* } & \multirow{2}{*}{ CV (\%) } \\
\cline { 2 - 4 } & $0 \%$ & $1.5 \%$ & $3.0 \%$ & $4.5 \%$ & & \\
\cline { 2 - 4 } Dry matter (DM) & 78.3 & 83.7 & 91.9 & 86.2 & $\mathrm{Y}=85.0$ & 21 \\
Digestible DM & 61.3 & 63.8 & 69.4 & 63.0 & $\mathrm{Y}=64.4$ & 25 \\
Organic matter (OM) & 70.5 & 74.7 & 80.4 & 73.6 & $\mathrm{Y}=74.8$ & 21 \\
Digestible OM & 56.2 & 57.6 & 61.0 & 53.6 & $\mathrm{Y}=57.1$ & 25 \\
Crude protein (CP) & 7.93 & 8.76 & 9.58 & 8.75 & $\mathrm{Y}=8.78$ & 21 \\
Digestible CP & 5.78 & 6.09 & 6.71 & 5.67 & $\mathrm{Y}=6.06$ & 24 \\
Ether extract (EE) & $1.07^{\mathrm{b}}$ & $1.31^{\mathrm{ab}}$ & $1.52^{\mathrm{a}}$ & $1.44^{\mathrm{ab}}$ & $\mathrm{Y}=1.26$ & 20 \\
Digestible EE & $0.87^{\mathrm{b}}$ & $0.98^{\mathrm{ab}}$ & $1.24^{\mathrm{a}}$ & $1.14^{\mathrm{ab}}$ & $\mathrm{Y}=1.06$ & 23 \\
Neutral detergent fiber (NDF) & 24.1 & 24.0 & 29.5 & 26.9 & $\mathrm{Y}=26.1$ & 19 \\
Digestible NDF & 12.7 & 11.4 & 16.9 & 15.1 & $\mathrm{Y}=14.0$ & 29 \\
Acid detergent fiber (ADF) & 8.78 & 8.22 & 10.5 & 10.3 & $\mathrm{Y}=9.45$ & 24 \\
Digestible ADF & 5.11 & 4.33 & 5.78 & 4.94 & $\mathrm{Y}=5.04$ & 32 \\
Hemicellulose (HCEL) & 14.8 & 15.6 & 18.5 & 16.7 & $\mathrm{Y}=16.4$ & 19 \\
Digestible HCEL & 9.49 & 9.20 & 11.9 & 10.4 & $\mathrm{Y}=10.2$ & 24 \\
Cellulose (CEL) & $9.17^{\mathrm{ab}}$ & $8.47^{\mathrm{b}}$ & $11.0^{\mathrm{a}}$ & $9.58^{\mathrm{ab}}$ & $\mathrm{Y}=9.55$ & 19 \\
Digestible CEL & 5.00 & 3.84 & 5.51 & 4.75 & $\mathrm{Y}=4.78$ & 31 \\
Total carbohydrates (TCHO) & 60.0 & 68.1 & 76.5 & 72.4 & $\mathrm{Y}=69.2$ & 16 \\
Digestible TCHO & 45.8 & 52.7 & 57.5 & 54.0 & $\mathrm{Y}=52.5$ & 18 \\
Soluble CHO & 36.5 & 43.9 & 47.5 & 44.6 & $\mathrm{Y}=43.1$ & 17 \\
Digestible soluble CHO & 34.6 & 41.4 & 44.0 & 41.2 & $\mathrm{Y}=40.3$ & 6 \\
\hline
\end{tabular}

${ }^{\mathrm{a} D i f f e r e n t}$ letters within the same line indicate a difference according to Duncan's multiple range test $(P \leq 0.05)$. ${ }^{*} \mathrm{RE}=$ regression equations $(P \leq 0.05)$.

The inclusion of whey in the diets did not affect whey rations, ADF digestibility was greater relative nutrient digestibility (Table 4). In the 0 and $1.5 \%$ to NDF digestibility. 
Table 4

Digestibility of dry matter, organic matter, crude protein and ether extract (percentage of dry matter) of diets containing various contents of bovine milk whey fed to kids

\begin{tabular}{lcccccc}
\hline & \multicolumn{3}{c}{ Diet containing bovine milk whey } & \multirow{2}{*}{ RE* } & \multirow{2}{*}{ CV (\%) } \\
\cline { 2 - 5 } & $0 \%$ & $1.5 \%$ & $3.0 \%$ & $4.5 \%$ & & \\
\hline Dry matter & $77.2^{\mathrm{a}}$ & 75.9 & 74.9 & 73.2 & $\mathrm{Y}=75.3$ & 7 \\
Organic matter & 78.8 & 76.9 & 75.3 & 72.9 & $\mathrm{Y}=76.0$ & 7 \\
Crude protein & 72.0 & 69.2 & 69.6 & 65.0 & $\mathrm{Y}=68.9$ & 9 \\
Ether extract & 80.6 & 74.6 & 81.0 & 78.9 & $\mathrm{Y}=78.8$ & 6 \\
Neutral detergent fiber & 52.1 & 47.2 & 56.1 & 56.1 & $\mathrm{Y}=52.9$ & 11 \\
Acid detergent fiber & 57.9 & 51.5 & 54.5 & 47.9 & $\mathrm{Y}=52.9$ & 14 \\
Hemicellulose & 64.1 & 59.2 & 64.0 & 62.5 & $\mathrm{Y}=62.4$ & 10 \\
Cellulose & 54.1 & 45.2 & 49.2 & 49.2 & $\mathrm{Y}=49.4$ & 15 \\
Total carbohydrate & 75.1 & 75.2 & 74.4 & 75.2 & $\mathrm{Y}=75.0$ & 4 \\
Soluble carbohydrates & 95.5 & 95.0 & 92.4 & 91.7 & $\mathrm{Y}=93.6$ & 6 \\
\hline
\end{tabular}

${ }^{a}$ Different letters within the same line indicate a difference according to Duncan's multiple range test $(P \leq 0.05)$. ${ }^{*} E=$ regression equations $(P \leq 0.05)$.

There were no differences in $\mathrm{N}$ balance, $\mathrm{N}$ intake and urinary $\mathrm{N}$ among diets (Table 5). Animals fed $4.5 \%$ whey had greater fecal $\mathrm{N}$ excretion compared to the control group, while both of these did not differ from the 1.5 and $3.0 \%$ groups. Animals submitted to diets with $3.0 \%$ whey retained more
$\mathrm{N}$ than those fed $4.5 \%$ but were undifferentiated from other treatments. The increase in fecal $\mathrm{N}$ in animals fed $4.5 \%$ whey did not compromise protein digestibility (Table 4). Evidently the decrease in $\mathrm{N}$ retention by animals in the $4.5 \%$ treatment was due to greater fecal $\mathrm{N}$ excretion.

Table 5

Percentages of nitrogen $(\mathrm{N})$ intake, fecal $\mathrm{N}$, urine $\mathrm{N}, \mathrm{N}$ balance and $\mathrm{N}$ retained in kids fed various contents of bovine milk whey

\begin{tabular}{|c|c|c|c|c|c|c|}
\hline & \multicolumn{4}{|c|}{ Percent whey in diet } & \multirow{2}{*}{$\mathrm{RE}^{*}$} & \multirow{2}{*}{$\mathrm{CV}(\%)$} \\
\hline & $0 \%$ & $1.5 \%$ & $3.0 \%$ & $4.5 \%$ & & \\
\hline $\mathrm{N}$ intake & 10.7 & 11.5 & 13.0 & 12.8 & $\mathrm{Y}=12.0$ & 15 \\
\hline Fecal N & $3.14^{\mathrm{b}}$ & $3.70^{\mathrm{ab}}$ & $4.15^{\mathrm{ab}}$ & $4.54^{\mathrm{a}}$ & $\mathrm{Y}=3.88$ & 23 \\
\hline Urinary $\mathrm{N}$ & 1.21 & 1.24 & 0.97 & 1.20 & $\mathrm{Y}=1.15$ & 20 \\
\hline $\mathrm{N}$ balance & 6.40 & 6.59 & 7.90 & 7.05 & $\mathrm{Y}=6.98$ & 17 \\
\hline Retained N & $58.5^{\mathrm{ab}}$ & $57.2^{\mathrm{ab}}$ & $60.5^{\mathrm{a}}$ & $55.3^{\mathrm{b}}$ & $Y=57.9$ & 5 \\
\hline
\end{tabular}

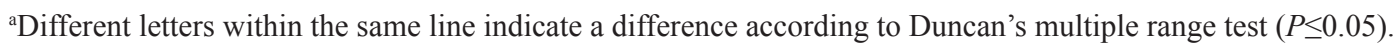

$* \mathrm{RE}=$ Regression equations $(P \leq 0.05)$.

There were no differences in TE and ME, (Table 6). Regression analyses resulted in no digestibility of $\mathrm{TE}$, concentration of $\mathrm{ME}$ as a significant equations for these parameters. proportion of DM, or energy balance among diets 
Table 6

Consumption and digestibility of total energy (TE), metabolizable energy (ME) intake and their proportion of dry matter (DM) intake (ME/DM) (Kcal/kg) and the balance of ME in kids fed various contents of bovine milk whey

\begin{tabular}{|c|c|c|c|c|c|c|}
\hline & \multicolumn{4}{|c|}{ Percentage of whey in diets } & \multirow{2}{*}{$\mathrm{RE}^{*}$} & \multirow{2}{*}{$\mathrm{CV}(\%)$} \\
\hline & $0 \%$ & $1.5 \%$ & $3.0 \%$ & $4.5 \%$ & & \\
\hline $\mathrm{TE}\left(\mathrm{g} / \mathrm{kg}^{0.75}\right)$ & 312.5 & 343.5 & 393.1 & 374.4 & $Y=355.9$ & 21.0 \\
\hline TE digestibility & 73.8 & 75.5 & 72.8 & 74.5 & $\mathrm{Y}=74.1$ & 7.0 \\
\hline ME (Mcal/kg) & 1.99 & 1.92 & 2.24 & 2.22 & $\mathrm{Y}=2.09$ & 33.0 \\
\hline $\mathrm{ME} / \mathrm{DM}$ & 2745 & 2625 & 2787 & 2785 & $Y=2735$ & 15.0 \\
\hline ME balance & 2045 & 1970 & 2291 & 2268 & $Y=2143$ & 32.0 \\
\hline
\end{tabular}

$* \mathrm{RE}=$ Regression equations $(P \leq 0.05)$.

\section{Discussion}

As whey addition to the concentrate increased, changes in feed consistency occurred. At 1.5\% whey, the concentrate was slightly humid while at $4.5 \%$ consistency became noticeably pasty. This change in consistency, however, did not affect feed acceptability by the animals; to the contrary, palatability appeared to increase.

For all treatments, animals preferred the concentrate over the forage and feed refusals consisted only of forage. El-Shewy (2016) observed that cows fed liquid supplements increased concentrate intake relative to cows with only water available to them. The author noted also that whey can improve the energy content of diets but requires adaptation and adequate $\mathrm{pH}(5.5-6.0)$ as well as roughage to avoid diarrhea. In our research, water intake was not measured so it was not possible to measure the effect of dietary whey on water intake. Ahmed, Mun, Islam and Yang, (2014), in a study on the effect of fermented liquid whey on growth performance, characteristics and meat quality of Hanwoo steers, observed an increase in body weight, average dairy gain and gain-to-feed ratio. They also reported that the high content of whey lactose can increase the energy content of diet and work to improve rumen fermentation.
Kids in the current trial did not have access to liquid whey but when mixed to concentrate, increasing moisture content of feeds with whey was observed. Thus, the moist concentrate may have facilitated feed intake as reflected by the shorter time it took for animals to ingest concentrates containing whey. El-Shewy (2016) observed that whey can improve feed palatability, texture, dust control of feedlot rations. Further, it can balance nutrition of energy, protein and minerals, and a safety factor to compensate for poor or variable quality diets.

Dry matter intake by growing lambs as proposed by NRC (2007) should be $530 \mathrm{~g} \mathrm{DM} \mathrm{day}^{-1}$, equivalent to $3.51 \%$ of LW. Diets in our trial resulted in intakes over this general recommendation. Likewise, CP daily consumption (greater than $70 \mathrm{~g} \mathrm{day}^{-1}$ ) in the experimental rations also resulted in $\mathrm{CP}$ consumption greater than those recommended by NRC (2007) which should fall between 42 a $46 \mathrm{~g}$ day $^{-1}$. Whey protein has greater availability to animals according to El-Shewy (2016). The inclusion of whey in the experimental feeds, however, did not increase CP digestibility in the rations (Table 4).

Even though there is greater EE digestibility of whey vis-á-vis maize and soybean, the amounts of whey in the experimental rations were insufficient to alter $\mathrm{EE}$ in the diets. Additionally, dietary fat did 
not exceed $4 \%$ (Table 2), a concentration that should not affect digestibility of fibrous portions of the ration according to Palmquist and Mattos (2006).

The innate feed selectivity of kids, in addition to the amount of rejected feed, resulted in greater intake of concentrate to the detriment of forage intake. Because the concentrate was mixed with the forage, diets containing whey had greater adhesion of concentrate to forage.

The positive $\mathrm{N}$ balance in the rations indicated that the animals were offered adequate protein to maintenance and growth. The $\mathrm{N}$ retained in growing ruminants can be used to anabolism, converting into muscle protein (Rezeai, Moharrery, \& Zamiri, 2019). The nitrogenous compounds reaching the rumen, from 50 to $70 \%$, are broken down, thereby releasing ammonia (Carvalho et al., 2010). In the case of highly soluble proteins such as those found in whey, most is converted into microbial proteins during rumen incubation, with irrelevant contribution to NDCP.

Diets containing whey fed to kids at the levels studied in this trial can contribute to $\mathrm{N}$ requirements for basal metabolism and animal protein synthesis. For this to happen, there must be energy available in the rumen to promote protein synthesis with an adequate amino acid profile. This appears to have occurred in the trial because there is a positive correlation between $\mathrm{N}$ intake and ME $(\mathrm{r}=0.90)$. Even with lactose present in whey, the reduced quantity of readily available carbohydrates vis-á-vis readily available whey protein (Smithers, 2008) may have had a deleterious effect on the synchronization of carbohydrate and protein degradation in the rumen. This may, in turn, have contributed to greater fecal $\mathrm{N}$ excretion and less $\mathrm{N}$ retention observed in animals fed $4.5 \%$ whey (Table 5).

Bovine milk whey, therefore, appears to be a useful alternative feed source because it did not negatively affect energy intake as measured by ME in all whey diets above those recommended by NRC (2007), namely 1.27 Mcal day ${ }^{-1}$. That greater increase contributed to a positive energy balance. The synchrony between dietary protein and energy must be balanced in the feed such that rumen microorganisms have these available not just in the correct amounts but the correct degradation rates in the rumen (Krehbiel, Bandyk, Hersom, \& Branine, 2008).

\section{Conclusions}

Bovine milk whey is an acceptable source of protein in growing, entire male kid diets. If it is included in diets up to $4.5 \%$ of diet, there are no negative effects on feed intake or apparent digestibility of those diets. If it is to be included in greater diet proportions than those studied here, care should be given to synchronize both amounts and degradability of protein and energy fractions.

\section{References}

Ahmed, S. T., Mun, H. S., Islam, M. M., \& Yang, C. J. (2014). Growth performance, carcass characteristics and meat quality of hanwoo steers fed fermented liquid whey inoculated with lactic acid bacteria. African Journal of Microbiology Research, 8(15), 1601-1609.

Bjorkman, M. P., Finne-Soveri, H., \& Tilvis, R. S. (2012). Whey protein supplementation in nursing home residents: a randomized controlled trial. European Geriatric Medicine, 3(3), 161-166. doi: 10.1016/j. eurger.2012.03.010

Cappelle, E. R., Valadares, S. C., F ., Coelho da Silva, J. F., \& Cecon, P. R. (2001). Estimates of the energy value from chemical characteristics of the feedstuffs. Revista Brasileira de Zootecnia, 30(6), 1837-1856. doi: 10.1590/S1516-35982001000700022

Carvalho, G. G. P., Garcia, R., Pires, A. J. V., Silva, R. R., Pereira, M. L. A., Viana, P. T.,... Pereira, T. C. J. (2010). Nitrogen balance, urea concentrations and microbial protein synthesis in goats fed diets containing sugar cane trated with calcium oxide. Revista Brasileira de Zootecnia, 39(10), 2253-2261. doi: 10.1590/S1516-35982010001000022

El-Shewy, A. A. (2016). Whey as feed ingredient for lactating cattle. Science International, 4(3), 80-85. doi: $10.17311 /$ sciintl.2016.80.85 
El-Tanboly, E., El-Hofi, M., \& Korshid. (2017). Recovery of cheese-whey, a by-product from the dairy industry for use as animal feed. Journal of Nutrition Health \& Food Engineering, 6(5), 148-154. doi: 10.15406/ jnhfe.2017.06.00215

Fundação Cearense de Meteorologia e Recursos Hídricos (2019). Dados climáticos do município de SobralCE, 2008. Recuperado de http://www.funceme.br

Huuskonen, A. (2017). Effect of skin milk and whey-based milk replacers on feed intake and growth of dairy calves. Journal of Applied Animal Research, 45(1), 480-484. doi: 10.1080/09712119.2016.1217868

Kanza, M. M., Sameen, A., Khan, M. U., Shariati, M. A., \& Hristova, V. K. (2017). Impact of cheese whey protein on growth performance of broiler: An approach of cheese utilization in poultry feed. Journal of Microbiology, Biotechnology and Food Sciences, 6(4), 1117-1120. doi: 10.15414/ jmbfs.2017.6.4.1117-1120

Krehbiel, C. R., Bandyk, C. A., Hersom, M. J., \& Branine, M. E. (2008). Alpharma beef cattle nutrition symposium: manipulation of nutrient synchrony. Journal of Animal Science, 86(14), 285-286. doi: $10.2527 /$ jas.2007-0788

Martins, T. D. D., Pimenta E. C., F F $^{o}$, Costa, R. G., \& Souza, J. H. M. (2008). Liquid serum form cheese as feeding supplement for growing pigs. Revista Ciência Agronômica, 39(2), 310-307. Retrieved from https://www.researchgate.net/ publication/288349649_Liquid_serum_from cheese_as_feeding_supplement_for_growing_pigs

Mollea, C., Marmo, L., \& Bosco, F. (2013). Valorisation of Cheese Whey, a By-Product from the Dairy Industry, Food Industry, Innocenzo Muzzalupo, IntechOpen. doi: 10.5772/53159. Available from: https://www.intechopen.com/books/food-industry/ valorisation-of-cheese-whey-a-by-product-fromthe-dairy-industry

National Research Council (2007). Nutrient requirements of small ruminants. Washington, DC: National Academy Press.

Palmquist, D. L., \& Mattos, W. R. S. (2006). Metabolismo de lipídeos. In T.T. Berchielli, A. V. Pires, \& S. G. Oliveira (Eds.), Nutrição de ruminantes. (pp. 287310). Jaboticabal: FUNEP.
$\mathrm{R}$ Core Team (2019). R: A language and environment for statistical computing. $R$ foundation for statistical computing, Vienna. Retrieved from https://R-project. org/

Rezeai, R., Moharrery, A., \& Zamiri, M. J. (2019). Growth performance, nutrient digestibility and nitrogen metabolism of Ram-lambs fed single feed protein. Animal Nutrition and Feed Technology, 19(1), 123-136. doi: 10.5958/0974-181X.2019.000 12.X

Rogério, M. C. P., Martins, E. C., Shiotsuki, L., Pompeu, R. C. F. F., Muir, J. P., Araújo A. R.,... Alves, A. A. (2019). Economic viability of finishing lambs in the feedlot using bovine cheese whey as dietary ingredient. Small Ruminant Research, 170, 131-136. doi: 10.1016/j.smallrumres.2018.11.018

Silva, D. J., \& Queiroz, A. C. (2002). Análise de alimentos: métodos químicos e biológicos (3a ed.). Viçosa, MG: Editora UFV.

Smithers, W. G. (2008). Whey to whey proteins - from 'gutter to gold. International Dairy Journal, 18(7), 695-704. doi: 10.1016/j.idairyj.2008.03.008

Sniffen, C. J., O'Connor, J. D., Van Soest, P. J., Fox, D. J., \& Russell, J. B. (1992). Anet carbohydrate and protein system for evaluating cattle diets. II. Carbohydrate and protein availability. Journal of Animal Science, 70(11), 3562-3577. doi: 10.2527/1992.70113562x

Van Soest, P. J. (1994). Nutritional ecology of the ruminant (2nd ed.). Ithaca: Cornell University Press.

Van Soest, P. J., Robertson, J. B., \& Lewis, B. A. (1991) Methods for dietary fiber, neutral detergent fiber, and nonstarch polysaccharides in relation to animal nutrition. Journal of Dairy Science, 74(10), 35833597. doi: 10.3168/jds. S0022-0302(91)78551-2

Yadav, J. S. S., Yan, S., Pilli, S., Kumar, L., Tyagi, R. D., \& Surampalli, R. Y. (2015). Cheese whey: a potential resource to transform into bioprotein, functional/nutritional proteins and bioactive peptides. Biotechnology Advances, 33(6), 756-774. doi: 10.1016/j.biotechadv.2015.07.002 